\title{
Digital Immigrants and Digital Natives: Learning Business Informatics at Higher Educational Level
}

\section{Dalia Suša}

Faculty of Economics and Business, University of Zagreb, Croatia

\section{Abstract}

Background: The term digital natives refer to those born since the 1980 s and have been growing up surrounded by technology. On the other hand, digital immigrants are born before 1980s and learned how to use technology later in life. Objectives: Goal of the paper is to explore attitudes of digital native students on the course of Business Informatics at higher educational institutions (HEls), and to compare them with attitudes of digital immigrants. Methods/Approach: The survey was conducted in 2014 using the sample of first-year Business Informatics students from the Faculty of Economics and Business in Zagreb, Croatia. Results were compared with a research conducted in 1998. Results: In comparison to an earlier research, digital natives perceive their level of competency in the subject of Business Informatics before teaching practices much higher compared to digital immigrants. However, there is still an increase in digital native students' level of competency in the subject before and after teaching practices. Conclusions: The research confirms a shift from digital immigrants to digital natives who show high level of interest for Business Informatics course topics and find its utility very high. However, constant improvement of delivering knowledge is needed in order to keep these high levels.

Keywords: digital natives; digital immigrants; information technology education; education improvement; business informatics

JEL main category: I

JEL classification: 123

Paper type: Research article

Received: 12, January, 2014

Accepted: 25, May, 2014

Citation: Suša, D. (2014), "Digital Immigrants and Digital Natives: Learning Business Informatics at Higher Educational Level", Business Systems Research, Vol. 5, No. 1, pp. 84-96.

DOI: $10.2478 / \mathrm{bsrj}-2014-0012$

Acknowledgments: This paper has been written with the guidance of Professor Mirjana Pejić-Bach, who gave useful advice regarding the methodology, composition and the title of the paper. 


\section{Introduction}

In 2001 Prensky invented the terms digital natives, referring to students born in the environment full of technology, and digital immigrants referring to those who learned how to use technology later in their lives. He describes modern students saying that nowadays students are "native speakers of the digital language" (Prensky, 2001, pp. 1). Although Prensky is not specific about the timing, some authors claim that students born after 80' ' can be considered as a new generation (Palfrey \& Gasser, 2008; Tapscott, 2008; Salajan et al., 2010), and those born before 80s' as digital immigrants (Salajan et. al, 2010; Margaryan et al., 2011). However, Joiner et al (2013) argue that one cannot simply talk about digital natives as a single generational group, rather than two generations; first being those born after 1980, and the second one including those born after 1993. Some authors go even further, naming those born after 1993 Google generation (Rowlands et al., 2008; Gunter et al., 2009; Boukacem-Zeghmouri \& Schöpfel, 2013), i-Generation (Rosen, 2010) , Homo Zappiens (Veen, 2003; Veen \& Vrakking, 2006) or Screenagers (Rushkoff, 2006, Yoon et al., 2013).

Regarding the digital natives' attitudes towards learning, Prensky (2001, pp. 1) claims that modern students have "changed radically" and that existing educational system is no longer suitable for them. Prensky (2010, pp. 19) argues that teachers as digital immigrants "are failing to deliver what students need in the ways they need it". This claim could be especially dangerous in case of ICT courses, since teachers need to deal with increasing power of technology; they also need to find the ways to teach ICT skills to digital native students enrolling universities. On the other hand, as it is assumed that we are referring to students who were born surrounded by technology, a question about the content, the approach and the way of teaching of the ICT courses could be raised. Additionally, some authors researched the existence and learning attitudes of digital natives (e.g. Jones et al., 2008; Ng, 2012) while others argue against the digital immigrants-digital natives gap and the existence of the specific new global generation in form of digital natives who have different learning needs (e.g. Guo et al., 2008; Waycott, 2010; Margaryan et al., 2011; Thompson, 2013).

Course of Business Informatics is taught at business colleges and/or universities, with different names covering similar subject taught (e.g. Business Information Systems, Management Information Systems, Information Technology). At the Faculty of Economics and Business in Zagreb, Croatia, the course of Business Informatics has been taught for more than 40 years (since $\left.70 s^{\prime}\right)$.

For continuous quality improvement of teaching business informatics it is important to receive students' feedback in order to improve the quality of courses and teachers' approach to the given topics. Course coordinators regularly conduct surveys in order to improve Business Informatics teaching practice. The results of one of the surveys conducted in the academic year 1997/1998 and carried out in May 1998 were published (Pejić Bach et al., 1999) in order to increase the visibility of the continuous improvement of the quality of teaching among the experts and other professors at HEls in Croatia.

Considering the shift among two generations between digital immigrant students to digital native students since the 1998 publication, new researches were conducted in order to measure and track the results, and compare the results among those two groups of students. Therefore, the purpose of this paper is to compare the 1998 research to the one conducted in 2014 and to see if there is any differences and how the technology affected generations and teaching process since 1998. In this paper we refer to the students participating in the survey in 1998 as 
digital immigrants, and to the students participating in the survey in 2014 as digital natives. Therefore, in this paper, results of the 2014 research (digital native students) will be analysed and presented as well as compared to the 1998 research (digital immigrants). In order to meet the objectives of this paper, there were four research questions defined:

- RQ1 - Are there significant differences in level of competences in the subject before the Business Informatics teaching practices between the 1998 and 2014 research results?

- RQ2 - Are there significant differences in level of competences in the subject before and after the Business Informatics teaching practices to digital natives?

- RQ3 - What is the digital natives' level of interest towards Business Informatics course topics?

- RQ4 - What is the opinion of digital natives to the Business Informatics course according to its utility? Do they perceive the utility of the course?

Paper is outlined as followed. After the introduction part of the paper, methodology of the research and data collecting are given in the second part of this paper. Results are presented in the third part. In the fourth part of the paper a brief discussion is given followed by answers to the research questions and the conclusion as the final, fifth part of this paper.

\section{Background}

Back in 1998, the Business Informatics course had some similarities and some differences with the current one, in 2014. According to Pejić Bach et al. (1999) and Bosilj Vukšić et al. (1999) in 1998 Business Informatics course was brought to the students on a weekly basis, every week there was two-hour lectures and two-hour teaching practices. Each students' lecture group was divided into two smaller ones for the teaching practices, about 35 students per group. Because of the lack of the available computers, students were supposed to work in pairs during the teaching practice. Professors of the department regularly publish books with exercises that are used at the classes (Kardum et al., 2000; Pejic-Bach et al., 2004; Knezevic et al., 2006; Bosilj Vukšić et al., 2009).

Nowadays, the first-year Business Informatics course at the Faculty of Economics and Business in Zagreb also consists of two parts, one being theoretical lectures carried out by the professors and the other being teaching practices carried out by the teaching assistants with the help of Departments' senior student assistants. Both parts of the Business Informatics course are performed simultaneously during the semester, each once a week by two-hour session. Unfortunately, constraints in form of the number of available computers and the classroom size still exist, so students lecture sections are being divided into smaller ones for the teaching practices where students work in pairs.

As far as the curriculum is concerned, significant changes have been made since 1998. For example, in 1998 teaching practices had 4 teaching goals on how to use: (1) word processor, (2) spreadsheets, (3) Internet and e-mail and (4) search engines. Students were learning "by example" with each class being organized around solving a specific business problem. (Pejić Bach et al., 1999) In the academic year 2013/2014, Business Informatics teaching practice included 7 teaching fields: (1) computer fundamentals, (2) word processing, (3) public presentations, (4) spreadsheets, (5) Internet services in business, (6) desktop publishing and (7) business Web sites. Additionally, for the first time, in academic year 2013/2014, students were taught how to use Google drive tools. Students still learn "by example", but since 1998 exercises became more complex and difficult so students can achieve more 
advanced level of knowledge after finishing the course. At the end of the course, in order to be able to take theoretical exam, students are supposed to show their achieved level of competency in the subject by taking a practical exam consisted of a series of related business problems. Such test is performed on computers.

The 2014 surveyed students may be considered as a second generation of digital natives, since most of them were born in 1994 or in 1995. On the other hand, students surveyed in 1998 research were most likely born in 1979 or 1980, so they can be considered as digital immigrants.

\section{Methodology}

In order to full-fill the goals of the paper, and to track changes since the research conducted in 1998, and for the purpose of this research, a survey has been conducted in January 2014 at the Department of Informatics, Faculty of Economics and Business, University of Zagreb. The survey has been designed and implemented at the initiative of the Department of Informatics as part of their constant effort to improve the quality of curriculum and Business Informatics teaching practices.

The 1998 survey was carried out in May 1998 on the sample of 636 first-year students enrolled in the Business Informatics course. The survey was carried out by the teaching assistants during the class, at the end of the year. The 1998 research was oriented towards students' previous knowledge of IT and its increase after the course, utility of the teaching practice, what students like and dislike and would add to the teaching practice. (Pejić Bach et al., 1999)

Similarly, the 2014 survey was carried out by teaching assistants during the class in the last week of lectures on a sample of 492 first-year students of the Business Informatics course. It consisted of a 22 questions, of which 6 of them were open-end questions regarding the advantages and disadvantages of the theoretical lectures and teaching practices and possible improvement suggestions. Furthermore, there were 7 Likert-scale questions regarding students' self evaluation of the level of knowledge and competencies in the subject before and after the course, course utility and the level of interest for the Business Informatics course topics. For the purpose of this paper, only the results related to the teaching practice were taken into account. The means, standard deviations and frequencies have been calculated for the Likert-scale statements.

\section{Results}

\section{Differences in level of competency between digital natives and digital immigrants before participating in the course}

First research question is concentrated on the students' self evaluation of the level of overall competency in the subject before they had any Business Informatics teaching practice at the first year of their studies. The question was: "How would you evaluate your level of competency in the subject before any Business Informatics teaching practice, on a scale of 1 to 5, with 1 being "No knowledge" and 5 being "Excellent knowledge"?". Table 1 presents comparative results from the 1998 and 2014 researches.

Digital natives in 2014 evaluate their level of overall competency in the subject significantly higher than digital immigrants in 1998 (Table 1). In 2014 most of the digital natives evaluate their knowledge really high, with $32.52 \%$ being excellent and $43.29 \%$ being very good. On the contrary, digital immigrants in 1998 evaluated their level of overall competency in the subject much lower; as $30.97 \%$ of the surveyed students answered they had only some level of overall competency in the subject 
before the Business Informatics teaching practice. Chi-square test revealed that the difference between the students' level of overall competency in the subject before the Business Informatics teaching practices in 1998 (digital immigrants) and in 2014 (digital natives) is statistically significant at $1 \%\left(\chi^{2}=75.327\right.$, p-value=0.000).

Table 1

Students' level of overall competency in the subject before participating in the course of Business Informatics in 1998 and in 2014

\begin{tabular}{|c|c|c|c|}
\hline $\begin{array}{l}\text { Level of competency in the subject } \\
\text { before participating the course }\end{array}$ & $1998(\%)$ & $2014(\%)$ & $\begin{array}{r}\text { Chi-square } \\
\text { (p-value) }\end{array}$ \\
\hline Excellent & $5.19 \%$ & $32.52 \%$ & \multirow{7}{*}{$\begin{array}{r}75.327 \\
\left(0.000^{*}\right)\end{array}$} \\
\hline Very good & $15.88 \%$ & $43.29 \%$ & \\
\hline Good & $25.63 \%$ & $19.92 \%$ & \\
\hline Some & $30.97 \%$ & $3.66 \%$ & \\
\hline None & $20.91 \%$ & $0.61 \%$ & \\
\hline No response & $1.42 \%$ & $0.00 \%$ & \\
\hline Total & $100.00 \%$ & $100.00 \%$ & \\
\hline
\end{tabular}

Source: Pejić Bach et al. (1999); Authors' survey (2014)

Note: *statistically significant at $1 \%$ level

If the collected data about the level of competency in the subject before any Business Informatics teaching practice is observed by the teaching fields, it is obvious that the trend showed by the digital immigrants in 1998 still exists in 2014. Surveyed students evaluate their level of competency higher when it comes to the operating system teaching field or word processor teaching field, while the level is lower in case of spreadsheets teaching field and Internet teaching field, but with significantly higher levels evaluated by digital natives in 2014 than digital immigrants in 1998. Chisquare test revealed that the difference between the students' level of competency in the subject before the Business Informatics teaching practices between digital immigrants in 1998 and digital natives in 2014 is statistically significant at $1 \%$ for all observed teaching fields (for operating system $\chi^{2}=51.899$, $\mathrm{p}$-value $=0.000$; for word processor $\chi^{2}=50.293$, $\mathrm{p}$-value=0.000; for spreadsheets $\chi^{2}=38.135$, $\mathrm{p}$-value $<0.000$ and for Internet $\chi^{2}=65.933$, p-value=0.000).

Table 2

Students' level of overall competency in the subject before participating in the course of Business Informatics in 1998 and in 2014 in different fields

\begin{tabular}{|c|c|c|c|c|c|c|c|c|}
\hline \multirow{2}{*}{$\begin{array}{l}\text { Level of } \\
\text { competency in } \\
\text { the subject }\end{array}$} & \multicolumn{2}{|c|}{$\begin{array}{l}\text { Operating } \\
\text { system (\%) }\end{array}$} & \multicolumn{2}{|c|}{$\begin{array}{c}\text { Word processor } \\
(\%)\end{array}$} & \multicolumn{2}{|c|}{$\begin{array}{c}\text { Spreadsheet } \\
(\%)\end{array}$} & \multicolumn{2}{|c|}{$\begin{array}{c}\text { Internet } \\
(\%)\end{array}$} \\
\hline & 1998 & 2014 & 1998 & 2014 & 1998 & 2014 & 1998 & 2014 \\
\hline Excellent (5) & $15.09 \%$ & $53.46 \%$ & $13.21 \%$ & $43.50 \%$ & $8.81 \%$ & $20.53 \%$ & $9.28 \%$ & $22.76 \%$ \\
\hline Very good (4) & $22.01 \%$ & $27.44 \%$ & 22. & & $18.40 \%$ & & & \\
\hline Good (3) & $22.48 \%$ & $4.23 \%$ & $0 \%$ & $3 \%$ & $20.60 \%$ & $2.72 \%$ & $13.36 \%$ & $28.05 \%$ \\
\hline Sol & & & & & & & & \\
\hline None (1) & $14.78 \%$ & $22 \%$ & $16.82 \%$ & $1 \%$ & & $2.64 \%$ & $47.96 \%$ & $3.46 \%$ \\
\hline No response & $0.00 \%$ & & & $0.00 \%$ & $0.00 \%$ & $0.00 \%$ & $0.63 \%$ & $0.00 \%$ \\
\hline Total & $100.00 \%$ & $100.00 \%$ & $100.00 \%$ & $100.00 \%$ & $100.00 \%$ & $100.00 \%$ & $100.00 \%$ & $100.00 \%$ \\
\hline Chi-square & & 51.899 & & 50.293 & & 38.135 & & 65.933 \\
\hline$p$-value & & $0.000^{*}$ & & $0.000^{*}$ & & $<0.001^{*}$ & & $0.000^{*}$ \\
\hline
\end{tabular}

Source: Pejić Bach et al. (1999); Authors' survey (2014)

Note: *statistically significant at $1 \%$ level 
Figure 1 shows students' level of competency in the subject before Business Informatics course teaching practice by teaching practice fields. The results presented in table 2 have been calculated into average grades (means) and presented graphically as columns, where the dark blue columns represent the average grades by teaching fields for the digital immigrants in 1998, while the light blue columns represent the average grades for the digital natives in 2014. As it is visible from the figure 1, the biggest difference refers to the Internet section of the Business Informatics teaching practice.

Figure 1

Students' level of overall competency in the subject before participating in the course of Business Informatics in 1998 and in 2014 in different fields, Average Grade (1-none competency, 5-excellent competency)

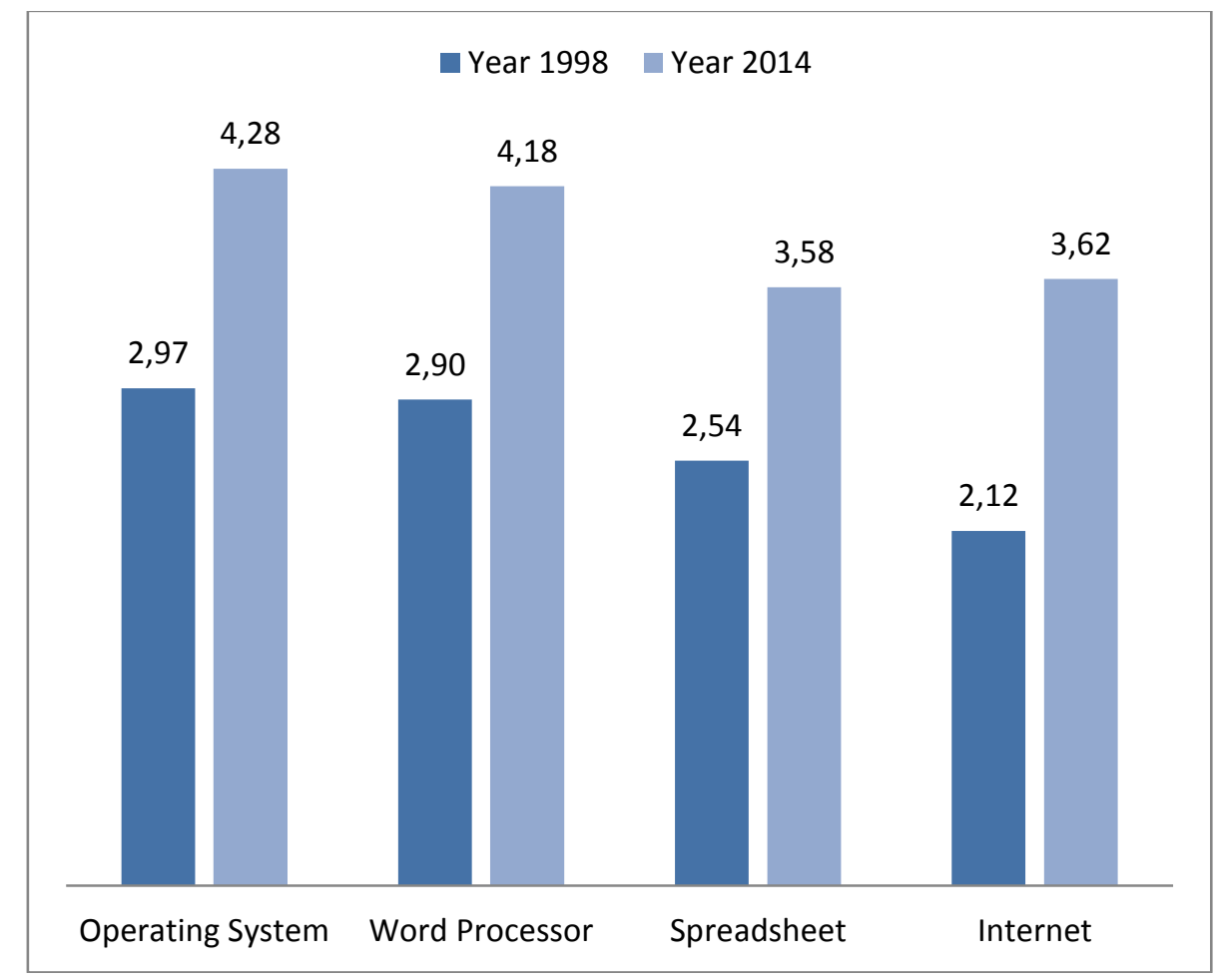

Source: Pejić Bach et al. (1999); Authors' survey (2014)

\section{Impact of the course to the competency in the field for digital natives}

If the data obtained from the 2014 survey questions about the level of competency in the subject before and after the Business Informatics teaching practice is compared on its average grade (mean) by the teaching fields, it is obvious that there is an increase in the level of knowledge for every field included in teaching practice, as the table 3 shows. Total average grade, with 1 being "None competency" and 5 being "Excellent competency", moves from 3.75 (standard deviation of 0.872) before the Business Informatics teaching practice to 4.42 (standard deviation of 0.782 ) for the after the teaching practice results. Paired t-test revealed that the difference between the digital natives' level of overall competency in the subject before and after the Business Informatics teaching practices in 2014 is statistically significant at $1 \%$ ( $t=17.264$, $p$-value $<0.001$ ). 
Table 3

Digital natives' level of competency in the subject by teaching fields before and after participating in the course, average grade (2014), (1-none competency, 5 excellent competency)

\begin{tabular}{|l|r|r|r|r|r|r|}
\hline \multirow{2}{*}{$\begin{array}{l}\text { Teaching field of Business } \\
\text { Informatics }\end{array}$} & \multicolumn{2}{|c|}{ Before practice } & \multicolumn{2}{|c|}{ After practice } & \multirow{2}{*}{ T-test } & \multirow{2}{*}{ P-value } \\
\cline { 2 - 5 } & Mean & St. dev. & Mean & St.dev. & & \\
\hline Computer fundamentals & 4.28 & 0.925 & 4.59 & 0.824 & 8.220 & $<0.001^{*}$ \\
\hline Word processing & 4.18 & 0.895 & 4.58 & 0.747 & 10.865 & $<0.001^{*}$ \\
\hline Public presentations & 3.99 & 0.966 & 4.48 & 0.822 & 12.221 & $<0.001^{*}$ \\
\hline Spreadsheets & 3.58 & 1.019 & 4.39 & 0.811 & 18.319 & $<0.001^{*}$ \\
\hline Internet services in business & 3.62 & 1.058 & 4.31 & 0.846 & 14.432 & $<0.001^{*}$ \\
\hline Desktop publishing & 3.42 & 1.152 & 4.27 & 0.899 & 16.196 & $<0.001^{*}$ \\
\hline Business Web sites & 3.40 & 1.165 & 4.32 & 0.887 & 17.443 & $<0.001^{*}$ \\
\hline $\begin{array}{l}\text { Total average level of overall } \\
\text { competency in the subject }\end{array}$ & 3.75 & 0.872 & 4.42 & 0.782 & 17.264 & $<0.001^{*}$ \\
\hline
\end{tabular}

Source: Authors' survey (2014)

Note: Students' self evaluation; *statistically significant at $1 \%$ level

However, if the level of competency in the subject is compared for each surveyed digital native student, the situation is slightly different, as shown in table 4. Majority of the digital natives answered that there's no change in the level of their competency before and after the teaching practice for the computer fundamentals (67.90\%), word processing (61.17\%) and public presentations (55.10\%). For the other teaching fields, there is an increase in the level of competency in the subject, especially for the spreadsheets field with the total $66.38 \%$ of the surveyed digital natives evaluated an increase by one, two, three, or four levels in their level of competency in the subject.

Table 4

Increase of student's level of competency before and after the teaching practices (2014)

\begin{tabular}{|c|c|c|c|c|c|c|}
\hline $\begin{array}{l}\text { Teaching field of } \\
\text { Business Informatics }\end{array}$ & $\begin{array}{c}\text { No } \\
\text { change } \\
\text { in levels } \\
(\%)\end{array}$ & $\begin{array}{c}\text { Increase } \\
\text { by } 1 \\
\text { level (\%) }\end{array}$ & $\begin{array}{c}\text { Increase } \\
\text { by } 2 \\
\text { levels } \\
(\%)\end{array}$ & $\begin{array}{c}\text { Increase } \\
\text { by } 3 \\
\text { levels } \\
(\%)\end{array}$ & $\begin{array}{c}\text { Increase } \\
\text { by } 4 \\
\text { levels } \\
(\%)\end{array}$ & $\begin{array}{c}\text { Total } \\
\text { increase } \\
(\%)\end{array}$ \\
\hline $\begin{array}{l}\text { Computer } \\
\text { fundamentals }\end{array}$ & $67.90 \%$ & $23.64 \%$ & $7.81 \%$ & $0.22 \%$ & $0.43 \%$ & $32.10 \%$ \\
\hline Word processing & $61.17 \%$ & $31.02 \%$ & $7.81 \%$ & $0.65 \%$ & $0.43 \%$ & $39.91 \%$ \\
\hline Public presentations & $55.10 \%$ & $33.84 \%$ & $9.98 \%$ & $0.87 \%$ & $0.43 \%$ & $45.12 \%$ \\
\hline Spreadsheets & $34.71 \%$ & $43.82 \%$ & $18.22 \%$ & $3.69 \%$ & $0.65 \%$ & $66.38 \%$ \\
\hline $\begin{array}{l}\text { Internet services in } \\
\text { business }\end{array}$ & $39.91 \%$ & $39.70 \%$ & $14.97 \%$ & $3.04 \%$ & $1.30 \%$ & $59.00 \%$ \\
\hline Desktop publishing & $34.71 \%$ & $35.14 \%$ & $21.26 \%$ & $4.77 \%$ & $2.39 \%$ & $63.56 \%$ \\
\hline Business Web sites & $38.18 \%$ & $34.71 \%$ & $19.31 \%$ & $6.72 \%$ & $2.82 \%$ & $63.56 \%$ \\
\hline
\end{tabular}

Source: Authors' survey (2014)

Note: Students' self evaluation

Level of interest for the Business Informatics teaching practice topics

When asked to evaluate the level of interest for the Business Informatics teaching practice by its teaching fields on a scale from 1 to 5 , with 1 being "Not interested" 
and 5 being "Extremely interested", digital natives expressed high level of interest for the Business Informatics teaching practice topics. The results are presented in table 5. It is visible that majority of the surveyed digital native students express their level of interest for the every teaching field as extremely interested or very interested.

Table 5

Digital natives' level of interest for the Business Informatics by teaching fields (2014)

\begin{tabular}{|l|c|c|r|r|r|}
\hline $\begin{array}{l}\text { Teaching field of Business } \\
\text { Informatics }\end{array}$ & $\begin{array}{c}\text { Not } \\
\text { interested } \\
(\boldsymbol{\%})\end{array}$ & $\begin{array}{c}\text { Slightly } \\
\text { interested } \\
(\boldsymbol{\%})\end{array}$ & $\begin{array}{c}\text { Somewhat } \\
\text { interested } \\
(\boldsymbol{\%})\end{array}$ & $\begin{array}{c}\text { Very } \\
\text { interested } \\
(\boldsymbol{\%})\end{array}$ & $\begin{array}{c}\text { Extremely } \\
\text { interested } \\
(\%)\end{array}$ \\
\hline Computer fundamentals & $3.25 \%$ & $7.52 \%$ & $18.70 \%$ & $33.94 \%$ & $36.59 \%$ \\
\hline Word processing & $2.24 \%$ & $6.91 \%$ & $16.87 \%$ & $37.60 \%$ & $36.38 \%$ \\
\hline Public presentations & $1.83 \%$ & $7.32 \%$ & $18.70 \%$ & $38.01 \%$ & $34.15 \%$ \\
\hline Spreadsheets & $1.83 \%$ & $7.32 \%$ & $20.53 \%$ & $36.18 \%$ & $34.15 \%$ \\
\hline Internet services in business & $1.42 \%$ & $5.49 \%$ & $19.31 \%$ & $40.04 \%$ & $33.74 \%$ \\
\hline Desktop publishing & $2.64 \%$ & $6.50 \%$ & $16.67 \%$ & $37.20 \%$ & $36.99 \%$ \\
\hline Business Web sites & $1.42 \%$ & $5.49 \%$ & $18.50 \%$ & $37.40 \%$ & $37.20 \%$ \\
\hline
\end{tabular}

Source: Authors' survey (2014)

Figure 2 presents the digital natives' average level of interest for the Business Informatics teaching fields on a scale from 1 to 5 , with 1 being "Not interested" and 5 being "Extremely interested". Presented results show that the average level of digital native students' interest for the teaching practice fields is high in its average total, being 3.98 with standard deviation 0.909 . If the collected data is observed field by field, as shown in figure 2, it is visible that the average level of interest for the Business Informatics teaching practice topics is high for every teaching field, and just slightly differs from field to field.

Figure 2

Digital natives' level of interest for the Business Informatics by teaching fields (2014), Average Grade (1-not interested, 5-extremely interested)

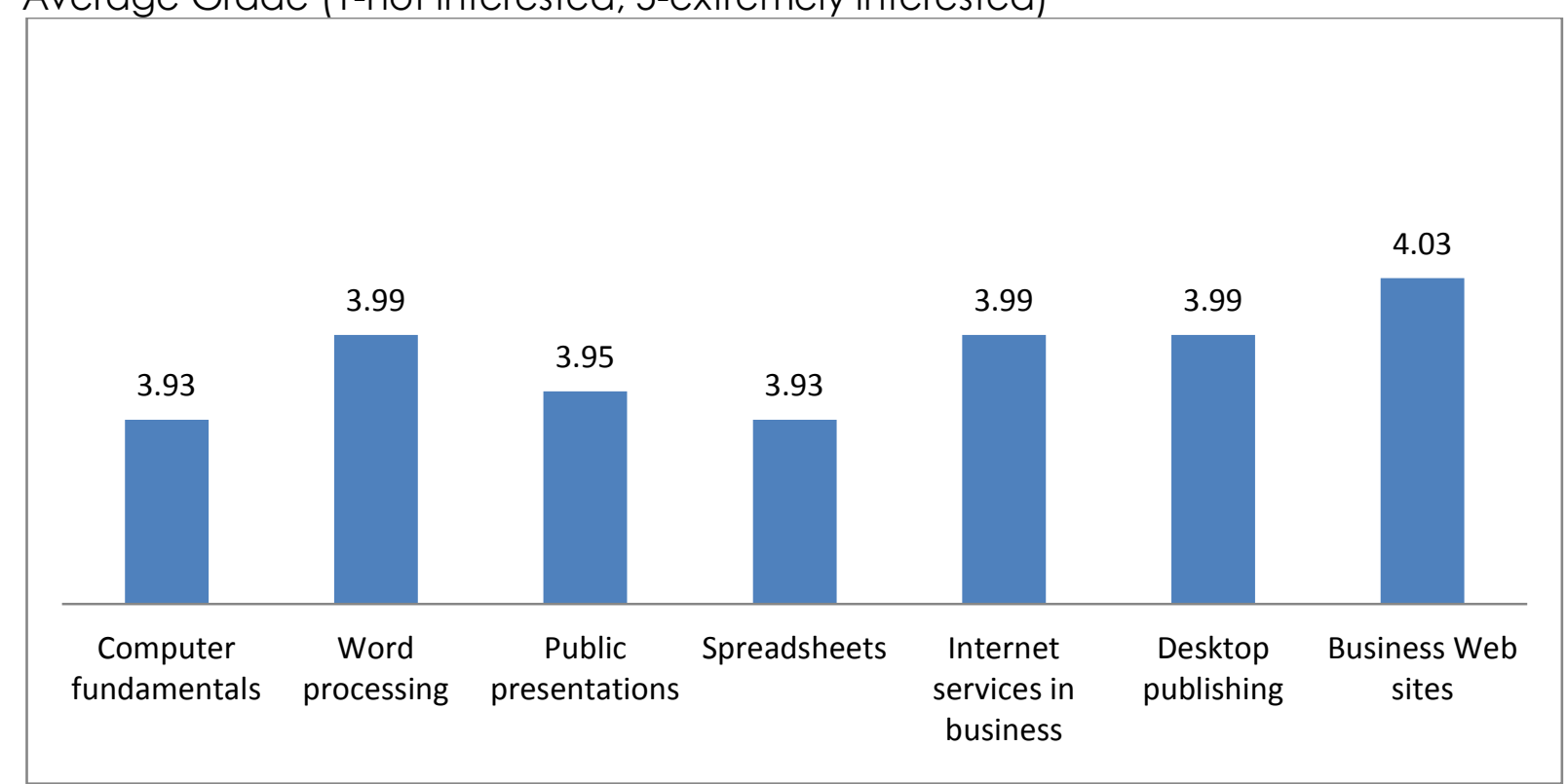

Source: Authors' survey (2014) 


\section{Utility of Business Informatics for digital natives}

In the 2014 research, digital natives were asked to rate the utility of the Business Informatics teaching practice by its fields on a scale from 1 to 5, with 1 being "None utility" and 5 being "Very high utility". The results are presented in table 6. As it is visible from the table 6, majority of the surveyed digital natives (above 50\%) think that Business Informatics teaching practice has very high utility of all teaching fields.

Table 6

Digital natives' rating of Business Informatics utility by teaching fields (2014)

\begin{tabular}{|l|r|r|r|r|r|}
\hline $\begin{array}{l}\text { Teaching field of Business } \\
\text { Informatics }\end{array}$ & $\begin{array}{c}\text { None } \\
\text { utility } \\
\mathbf{( \% )}\end{array}$ & $\begin{array}{c}\text { Low } \\
\text { utility } \\
\mathbf{( \% )}\end{array}$ & $\begin{array}{c}\text { Moderate } \\
\text { utility (\%) }\end{array}$ & $\begin{array}{c}\text { High } \\
\text { utility } \\
\text { (\%) }\end{array}$ & \multicolumn{1}{|l|}{$\begin{array}{c}\text { Very high } \\
\text { utility (\%) }\end{array}$} \\
\hline Computer fundamentals & $2.64 \%$ & $2.44 \%$ & $10.37 \%$ & $26.22 \%$ & $58.33 \%$ \\
\hline Word processing & $1.63 \%$ & $3.46 \%$ & $8.54 \%$ & $27.03 \%$ & $59.35 \%$ \\
\hline Public presentations & $2.24 \%$ & $2.64 \%$ & $10.16 \%$ & $25.81 \%$ & $59.15 \%$ \\
\hline Spreadsheets & $1.02 \%$ & $2.24 \%$ & $9.35 \%$ & $28.05 \%$ & $59.35 \%$ \\
\hline Internet services in business & $1.42 \%$ & $2.64 \%$ & $12.60 \%$ & $27.85 \%$ & $55.49 \%$ \\
\hline Desktop publishing & $1.63 \%$ & $3.46 \%$ & $11.18 \%$ & $31.30 \%$ & $52.44 \%$ \\
\hline Business Web sites & $1.63 \%$ & $3.05 \%$ & $10.77 \%$ & $30.28 \%$ & $54.27 \%$ \\
\hline
\end{tabular}

Source: Authors' survey (2014)

Figure 3 presents average grade of Business Informatics teaching practice utility by its teaching fields on a scale from 1 to 5, with 1 being "None utility" and 5 being "Very high utility". In its total average grade, digital native students' perception of Business Informatics teaching practice fields utility is high, being 4.37 with standard deviation 0.833. Similarly to the case of the surveyed digital natives' level of interest for the Business Informatics course teaching fields (see figure 2), average utility grades by Business Informatics teaching fields are very close, with almost negligible differences between them.

Figure 3

Digital natives' rating of Business Informatics utility by teaching fields (2014),

Average grade, (1-none utility, 5-very high utility)

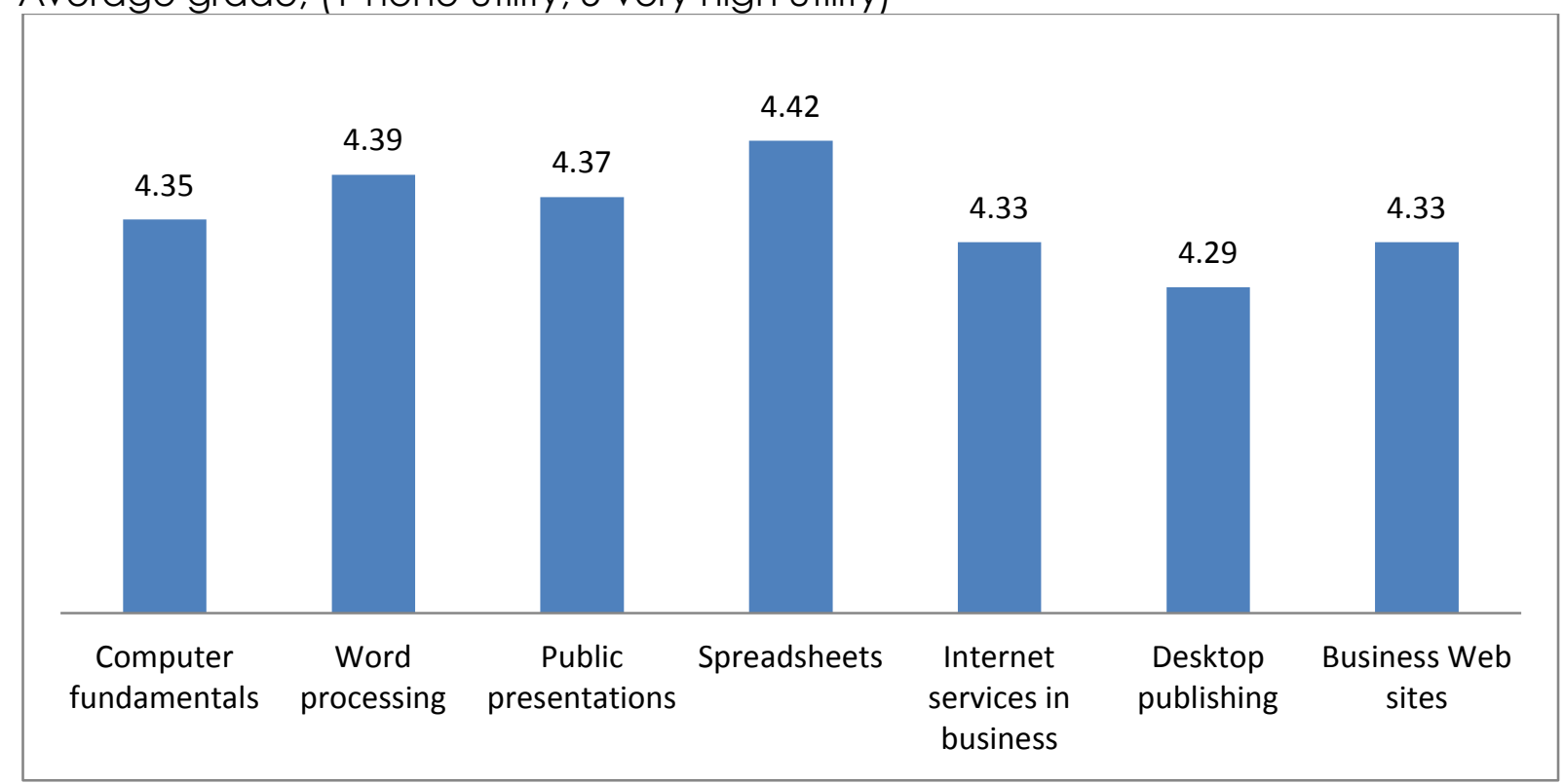

Source: Authors' survey 


\section{Discussion}

The results of the 1998 digital immigrants and 2014 digital natives research given in the previous part of the paper gave the answers to the research questions formed in the introduction.

First research question was concerned about the existence of significant differences in level of competency in the subject of Business Informatics before the teaching practices in 1998 and 2014 research results. As the results were presented, it has been shown that digital natives nowadays evaluate their ICT skills much higher than digital immigrants before. Furthermore, the chi-square test revealed these differences to be significant. This finding confirms the existence of digital natives generation, as a generation who speaks digital language more fluently and naturally than digital immigrants generation. The presented results also showed that the biggest shift between digital immigrants and digital natives in self-evaluation of their pre-course knowledge has been made in the Internet section of the Business Informatics teaching practice. This finding is not strange since the surveyed digital natives were born in 1994 or 1995 so they are the second generation of digital natives, who has been created with the rise of the Web 2.0 (Helsper \& Eynon, 2010). Similar to this papers' findings, in the 2008 research Jones et al. (2008) report that over $80 \%$ of surveyed UK university students have ICT confidence and skills.

In the second research question, the question was if there are significant differences in level of competences in the subject before and after the Business Informatics teaching practice to digital natives. The results showed that there has been a significant increase in the level of competency in the subject of the surveyed digital natives after the Business Informatics teaching practice. These findings could be compared to the Australian study which showed similar results in form of an increased level of digital natives' self-evaluated knowledge before and after the Informatics course with a shift in a mean value from 6.2 (pre-course) to 8.0 (postcourse) out of the maximum mean value 10 ( $\mathrm{Ng}, 2012)$.

The third research question was oriented towards the digital natives' level of interest for the Business Informatics course topics. The results revealed that surveyed digital natives have positive attitudes towards Business Informatics teaching practice fields and show high level of interest for them. This finding may explain the increase in the digital natives' level of competency in the subject after the Business Informatics teaching practice from the second research question, having in mind that digital natives, according to Prensky (2010), focus only on technology and topics that interests them and want to learn to use modern tools they can use in every-day life.

Finally, the fourth research question covered the issue of digital natives' utility perception of the Business Informatics teaching practices. The results showed high level of Business Informatics course utility perception by digital natives. This finding can be additionally supported by the already mentioned increase in the level of competency in the subject of Business Informatics revealed by the second research question. Although digital natives were born surrounded by technology, in many cases they still don't know how to use it in a business appropriate way and need to be taught to do so (Thompson, 2013). This could be because of the fact that they mostly use technology for social purposes and entertainment (Oliver \& Goerke, 2007; Selwyn, 2009).

Based on the research question answers, some practical recommendations could be given. Since the level of self-evaluation pre-course skills is high, Business Informatics teaching practice exercises should be revised and potentially adapted to suit the level of students' pre-course knowledge and the level of ICT competency. In order to keep the high level of interest for the Business Informatics course topics, it 
is highly important to keep track of trends and technology development and to offer students fresh ideas and every-day life examples. In that sense, using ICT case studies in the Business Informatics teaching practice is recommended. Also, students want to learn skills that are real and applicable right after they learn it, not "someday" (Prensky, 2010) so it is important that students can see the purpose and utility of the Business Informatics teaching practice exercises and the presented knowledge at all times.

\section{Conclusion}

To sum it up, the presented results showed that there has been a shift in the level of competency in the subject before Business Informatics teaching practice between two observed samples, representing digital immigrants and digital natives. The paper also showed that although nowadays we are teaching digital natives, majority of them gives the Business Informatics course teaching practice high utility grade and show high level of interest in ICT topics as they achieve an increase in their ICT skills after the Business Informatics course.

This paper has presented systematic approach to the Business Informatics course quality improvement at the Faculty of Economics and Business, University of Zagreb, Croatia. Also, the paper has given useful students' attitude research results in the form of understanding the needs and perception of digital natives, including practical recommendations and has given an indication for further research topics. However, a limitation of this research is in its timing. In other words, surveyed students were supposed to self evaluate their level of competences before and after the teaching practice, although the survey took place at the end of the semester. Having that in mind, future research will include two stages, both of them based on students' self evaluation of the level of competencies and their expectations, perceptions and attitudes towards Informatics course. First stage will consist of a precourse survey while the second one will consist of the post-course survey. That way the collected data may be more credible in terms of the students' self-evaluation, since the students will have to self-evaluate their level of competency before they actually participate in any teaching practices or lectures, at the very beginning of the semester, and then do it again at the very end of the semester, after they go through provided curriculum.

To conclude, this paper supports the existence of the digital natives generation as a generation of students who were born surrounded by technology and are fluent in the digital language. However, the findings of this paper does not support Prensky's claim that digital natives need radical change of the educational system (Prensky, 2001; Prensky, 2010). As the research questions revealed, digital natives show an increase in their level of ICT skills after the Business Informatics course which they enrolled by the "old-fashioned" educational laws. Also, they perceive the utility of this kind of Business Informatics teaching practice and show high level of interest for its topics. By taking these findings into account, a need for radical change of the educational system cannot be confirmed at this time.

\section{References}

1. Bosilj Vukšić, V., Pejić Bach, M. (2009), "Poslovna informatika", Zagreb: Element.

2. Bosilj Vukšić, V., Pejić Bach, M., \& Ćurko, K. (1999) "Obstacles in Teaching Informatics: The Case Study of Faculty of Economics-Zagreb", International Conference on Information and Intelligent Systems' 99. Available at CD 
Proceedings.

3. Boukacem-Zeghmouri, C., Schöpfel, J. (2013), „Beyond the Google generation: towards community-specific usage patterns of scientific information", Baker, D., Evans, W., Trends, Discovery, and People in the Digital Age, Chandos Publishing, Oxford, pp. 137-151.

4. Gunter, B., Rowlands, I., Nicholas, D. (2009) "Google Generation': what is the evidence?", Chandos Information Professional Series, Gunter, B., Rowlands, I., Nicholas, D., Chandos Publishing, Oxford, pp. 65-92.

5. Guo, R. X., Dobson, T., Petrina, S. (2008), "Digital natives, digital immigrants: an analysis of age and ICT competency in teacher education", Journal of Educational Computing Research, Vol. 38 No.3, pp. 235-254.

6. Helsper, E., Eynon, R. (2010), "Digital natives: where is the evidence?", British Educational Research Journal, Vol. 36 No. 3, pp. 503-520.

7. Joiner, R., Gavin, J., Brosnan, M., Cromby, J., Gregory, H., Guiller, J., Maras, P., Moon, A. (2013), "Comparing first and second generation digital natives' Internet use, Internet anxiety, and Internet identification", Cyberpsychology, Behavior, and Social Networking, Vol. 16 No. 7, pp. 549-552.

8. Jones, C., Ramanau, R., Cross, S., Healing, G. (2010), "Net generation or Digital Natives: Is there a distinct new generation entering university?", Computers \& Education, Vol. 54 No. 3, pp. 722-732.

9. Kardum, G., Knežević, B., Pejić-Bach, M., \& Spremić, M. (2000), "Informatički alati u poslovanju", Zagreb: mikrorad.

10. Knežević, B., Pejić-Bach, M., Spremić, M., Vlahović, N., \& Jaković, B. (2006), "Priručnik za vježbe iz informatike 2006./2007", Zagreb: Zagreb: mikrorad.

11. Margaryan, A., Littlejohn, A., Vojt, G. (2011), "Are digital natives a myth or reality? University students' use of digital technologies", Computers \& Education, Vol. 56 No. 2, pp. 429-440.

12. Ng, W. (2012), "Can we teach digital natives digital literacy?", Computers \& Education, Vol. 59 No. 3, pp. 1065-1078.

13. Oliver, B., Goerke, V. (2007), "Australian undergraduates' use and ownership of emerging technologies: Implications and opportunities for creating engaging learning experiences for the Net Generation", Australasian Journal of Educational Technology, Vol. 23 No. 2, pp. 171-186.

14. Palfrey, J., Gasser, U. (2008), "Born digital: Understanding the first generation of digital natives", New York, Basic Books.

15. Pejić Bach, M., Bosilj Vukšić, V., Ćurko, K. (1999), "Organisation and improvement of teaching practice in informatics", Journal of Information and Organizational Sciences, Vol. 23 No. 1, pp. 23-36.

16. Pejić-Bach, M., Spremić, M., \& Vlahović, N. (2004), "Priručnik za vježbe iz informatike 2004/2005", Zagreb: mikrorad.

17. Prensky, M. (2001), "Digital Natives, Digital Immigrants", On the Horizon, MCB University Press, Vol. 9 No. 5, pp. 1-6.

18. Prensky, M. (2010), "Teaching digital natives: Partnering for real learning", London, Corwin.

19. Rosen, LD. (2010), "Rewired understanding the i-Generation and the way they learn", New York, Palgrave Macmillian.

20. Rowlands, I., Nicholas, D., Williams, P., Huntington, P., Fieldhouse, M., Gunter, B., Withey, R., Jamali, H.R., Dobrowolski, T., Tenopir, C. (2008), "The Google generation: the information behaviour of the researcher of the future", Aslib Proceedings, Vol. 60 No. 4, pp. 290-310.

21. Rushkoff, D. (2006), "Screenagers: Lessons in Chaos from Digital Kids", 
Incorporated, Hampton Press.

22. Salajan, F.D., Schönwetter, D.J., Cleghorn, B.M. (2010), "Student and faculty intergenerational digital divide: Fact or fiction?", Computers \& Education, Vol. 55 No. 3, pp. 1393-1403.

23. Selwyn, N. (2009), "The digital native - myth and reality", Aslib Proceedings: New Information Perspectives, Vol. 61 No. 4, pp. 364-379.

24. Tapscott, D. (2008), "Grown up digital: How the Net generation is changing your world", New York, McGraw-Hill.

25. Thompson, P. (2013), "The digital natives as learners: Technology use patterns and approaches to learning", Computers \& Education, Vol. 65, pp. 12-33.

26. Veen, W. (2003), "A new force for change: Homo Zappiens", The Learning Citizen, No. 7, pp. 5-7.

27. Veen, W., Vrakking, B. (2006), "Homo Zappiens: Growing up in a digital age", London, Network Continuum Education.

28. Waycott, J., Bennett, S., Kennedy, G., Dalgarno, B., Gray, K. (2010), "Digital divides? Student and staff perceptions of information and communication technologies", Computers \& Education, Vol. 54 No. 4, pp. 1202-1211.

29. Yoon, S.Y., Lee, J., Lee, C.H. (2013), "Interacting with Screenagers in Classrooms", Procedia - Social and Behavioral Sciences, Vol. 103, pp. 534-541.

\section{About the author}

Dalia Suša graduated Managerial Informatics from the Faculty of Economics and Business in Zagreb, Croatia with diploma thesis Unified communications, which was awarded the Dean's Award for Excellence. She was employed as a teaching and research assistant at the Department of Informatics at the Faculty of Economics and Business, University of Zagreb. Her main research interests are unified communications, business process management, Web services, Web 2.0 technologies and e-learning. Author can be contacted at susa.dalia@gmail.com 